\title{
Comparison of serum calcium and magnesium levels between preeclamptic and normotensive healthy pregnant women
}

\author{
Shilpa Mittal ${ }^{1 *}$, M. K. S. Shaikh ${ }^{1}$, Ratna Thakur ${ }^{2}$, Darshana Jain ${ }^{1}$ \\ ${ }^{1}$ Department of Biochemistry, Sri Aurobindo Medical College \& P. G. Institute, Indore, M.P., India \\ ${ }^{2}$ Department of Obstetrics \& Gynaecology, Sri Aurobindo Medical College \& P. G. Institute, Indore, M.P., India
}

Received: 3 September 2014

Accepted: 19 September 2014

\author{
*Correspondence: \\ Dr. Shilpa Mittal, \\ E-mail: shilpamittal75@ rediffmail.com
}

Copyright: $\odot$ the author(s), publisher and licensee Medip Academy. This is an open-access article distributed under the terms of the Creative Commons Attribution Non-Commercial License, which permits unrestricted non-commercial use, distribution, and reproduction in any medium, provided the original work is properly cited.

\begin{abstract}
Background: Preeclampsia is idiopathic multisystem disorder specific to human pregnancy. Its incidence is $8-10 \%$ of total pregnancies in India. It is one of the leading causes of maternal and fetal morbidity and mortality worldwide. Alterations in serum calcium and magnesium levels have been suggested as effective factors in causing preeclampsia. The aim of this study was to compare serum calcium and magnesium levels in preeclamptic and normal pregnant women in third trimester of pregnancy.

Methods: The study was conducted in the department of biochemistry in collaboration with department of obstetrics and gynaecology, Sri Aurobindo medical college \& P. G. institute, Indore during the period January 2012 to January 2013. Subjects were divided into two groups: group-I included 100 preeclamptic women group-II included 100 age matched, healthy pregnant women. Serum calcium and magnesium was estimated by Arsenazo III method and by Calmagite method in ERBA CHEM-5 respectively (Enzymatic kit method).

Results: Serum levels of calcium $(8.27 \pm 0.37 \mathrm{mg} / \mathrm{dL}$ vs. $9.06 \pm 0.27 \mathrm{mg} / \mathrm{dL})$ and magnesium $(1.99 \pm 0.13 \mathrm{mEq} / \mathrm{L}$ vs. $2.03 \pm 0.13 \mathrm{mEq} / \mathrm{L}$ ) were significantly lower in preeclamptic women than the control group (i.e. healthy pregnant women).

Conclusions: Hypocalcaemia and hypomagnesaemia are seen in the preeclamptic women may be responsible for the vascular pathology associated with onset of preeclampsia. Hence it can be concluded that adjuvant supplementation of calcium and magnesium may prevent further progression of preeclampsia.
\end{abstract}

Keywords: Hypocalcaemia, Hypomagnesaemia, Preeclampsia

\section{INTRODUCTION}

The anatomical, physiological and biochemical adaptations that take place in women during the short span of human pregnancy are profound. ${ }^{1}$ Pregnancy is a normal physiological phenomenon with many biochemical changes ranging from alterations in electrolyte concentrations to more complex changes in cortisol and calcium metabolism. Pregnancy is associated with normal physiological changes that assist in nurturing and survival of the fetus. Biochemical parameters reflect these adaptive changes and are clearly distinct from the non-pregnant state.
Preeclampsia is idiopathic multisystem disorder specific to human pregnancy. Hypertension is a universal problem; and it complicates at least $10 \%$ of all the pregnancies. ${ }^{2}$ Preeclampsia is defined as the triad of hypertension, proteinuria and edema occurring after 20 weeks gestation in previously normotensive women. ${ }^{3}$ It is transient but potentially dangerous complication of pregnancy. Preeclampsia is still one of the leading causes of maternal and fetal morbidity and mortality. ${ }^{4}$

The pathophysiological mechanism is characterized by a failure of the trophoblastic invasion of the spiral arteries; leading to maladaptation of maternal spiral arterioles, 
which may be associated with an increased vascular resistance of the uterine artery and a decreased perfusion of the placenta. ${ }^{5}$ The results from many clinical studies show the relationship between the aggravation of the hypertensive complications and the change in concentrations of various chemicals in mother's serum. ${ }^{6}$

Interestingly, the significant reduction in serum calcium and magnesium are found in preeclamptic mothers. This result agrees with the physiological role of both calcium and magnesium in humans. ${ }^{7,8}$ Calcium plays a critical role in the function of vascular smooth muscles. ${ }^{2}$ Alteration of plasma calcium concentration leads to raised blood pressure. Magnesium act as co-factor for many enzymes (e.g. sodium potassium ATPase) and involved in peripheral vasodilatation. ${ }^{2,9,10}$ Some studies shows that blood calcium and magnesium have a relaxant effect on the blood vessels of pregnant women. ${ }^{9,11}$

\section{Aims and objectives}

- Now-a-days biochemical approach is implicated in order to prevent the complications in pregnancy and to improve the fetal outcome. There are various laboratory methods which can be useful in this regard.

- The aim of this study was to measure Serum levels of calcium and magnesium in preeclamptic women and to compare those with normal pregnant women in third trimester.

\section{METHODS}

The present study was conducted in the departments of biochemistry and obstetrics \& gynaecology, Sri Aurobino medical college \& P. G. institute, Indore. The ethical committee of SAMC \& PGI has approved this research work. We have collected data from 200 pregnant women; and were divided into two groups: group-I included 100 preeclamptic women group-II included 100 age matched, healthy pregnant women. The two groups did not differ in respect to age and scocio-economic strata.

Inclusion criteria were mild preeclamptic women with gestational age more than 28 weeks of pregnancy who had proteinuria +1 or +2 detected by dip-stick urine analysis method with base-line blood pressure more than or equal to $140 / 90 \mathrm{~mm}$ of $\mathrm{Hg}$ and may or may not had pitting Edema over feet. Asymptomatic pregnant women with gestational age more than 28 weeks of pregnancy with blood pressure less than 130/80 mm Hg \& no traces of protein in urine.

Exclusion criteria were women with past history of preeclampsia/eclampsia, diabetes mellitus, chronic hypertension, renal diseases and any other chronic illness and also women with the history of multiple pregnancies, under treatment of anti-epileptic drugs and family history of diabetes mellitus or hypertension.
Blood pressure was measured in semi-recumbent position. Proteinuria was measured by testing urine sample by dip-stick method. Pre-test and post-test counseling were given to the subjects. After taking written consent from the subjects, venous blood will be collected in vacutainer, allowed to clot and then immediately sent to the biochemistry lab. Where the samples will be centrifuged at $4000 \mathrm{rpm} \times$ for 10 minutes, then serum will be separated and analyzed for the following tests.

- The tests performed in our department:

1. Serum calcium was estimated by Arsenazo III method in ERBA CHEM-5 (Enzymatic kit method). ${ }^{12}$

2. Serum Magnesium was estimated by Calmagite method in ERBA CHEM-5 (Enzymatic kit method).

\section{RESULTS}

We have collected data for estimation of serum calcium and serum magnesium from 100 pregnant women with diagnosis of preeclampsia in the third trimester (Group-I) and 100 normal, age matched pregnant women in the third trimester (Group-II) as control for group-I; that admitted in the department of obstetrics and gynaecology for parturition. And we found that the mean serum calcium levels in preeclamptic group and in control group were $8.27 \pm 0.37 \mathrm{mg} / \mathrm{dL}$ and $9.06 \pm 0.27 \mathrm{mg} / \mathrm{dL}$ respectively. While the mean Serum Magnesium levels in cases of Preeclampsia were $1.99 \pm 0.13 \mathrm{mEq} / \mathrm{L}$ and in controls it was $2.03 \pm 0.13 \mathrm{mEq} / \mathrm{L}$. There was significant decrease in the serum levels of calcium and magnesium in preeclamptic cases when compared with the control group. Results of the present study have been shown by the following Figures and Tables.

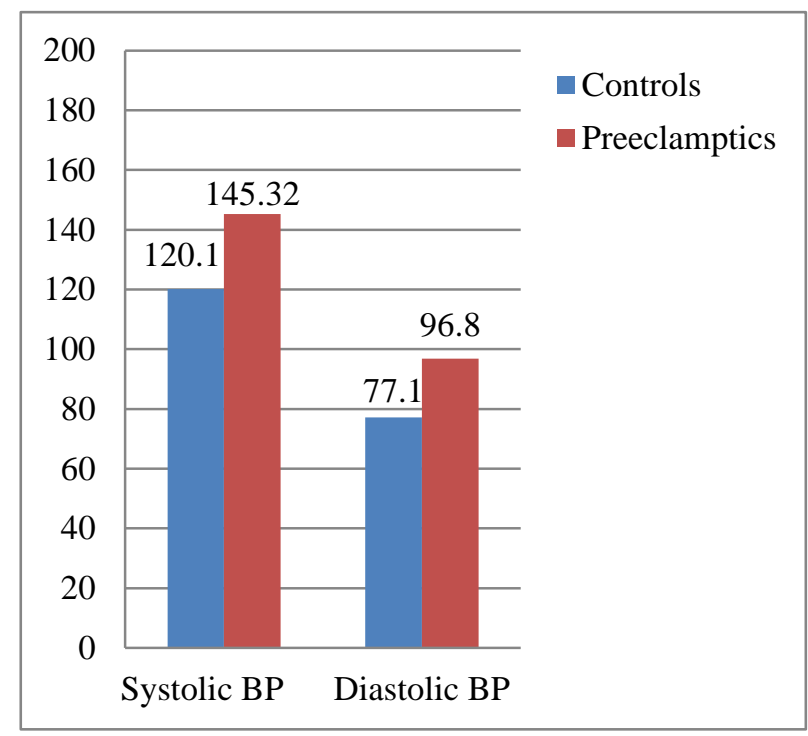

Figure 1: Comparison of blood pressure in preeclamptics and control groups. 
Table 1: Comparison of blood pressure in preeclamptics and control groups.

\begin{tabular}{|lll|}
\hline Group & $\begin{array}{l}\text { Mean systolic } \\
\text { blood pressure } \\
(\mathrm{mm} \text { Hg) with SD }\end{array}$ & $\begin{array}{l}\text { Mean diastolic } \\
\text { blood pressure } \\
(\mathbf{m m} \text { Hg) with SD }\end{array}$ \\
\hline Preeclamptics & $145.32 \pm 6.66$ & $96.8 \pm 5.00$ \\
\hline Control & $120.1 \pm 7.54$ & $77.1 \pm 5.03$ \\
\hline P value & $<0.0001$ & $<0.0001$ \\
\hline
\end{tabular}

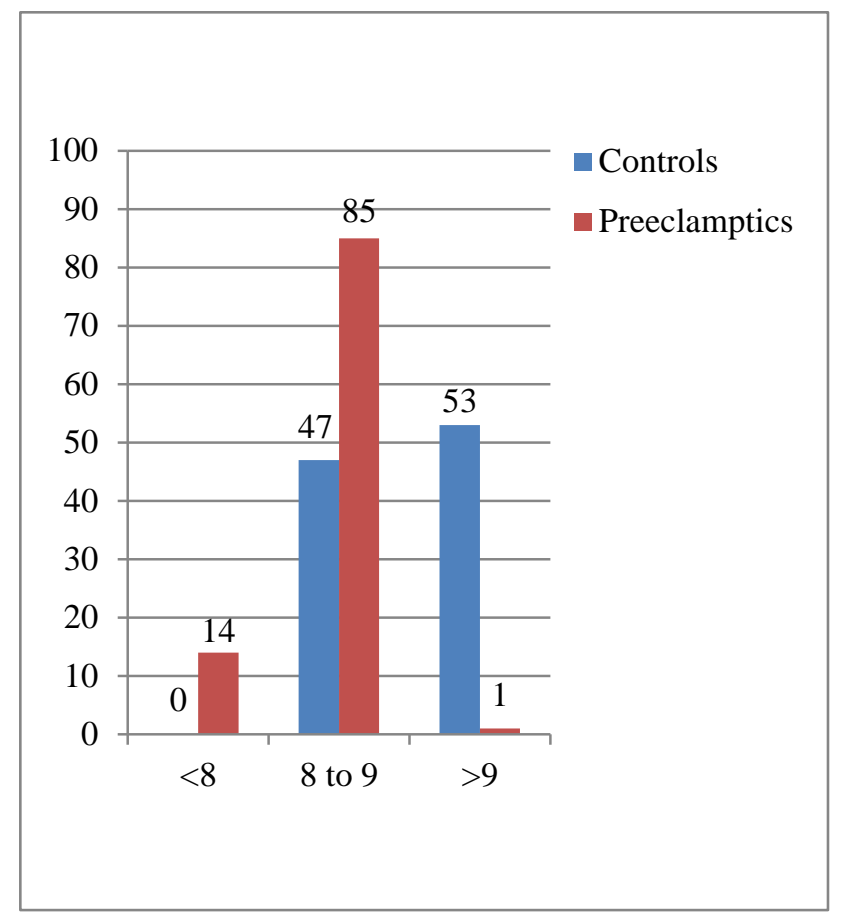

Figure 2: Comparison of serum calcium between preeclamptics and control groups.

Table 2: Comparison of serum calcium between preeclamptics and control groups.

\begin{tabular}{|c|c|c|c|}
\hline Group & $\begin{array}{l}\text { Serum calcium } \\
(\mathrm{mg} / \mathrm{dL}) \\
\text { Mean } \pm \text { SD }\end{array}$ & P value & Inference \\
\hline Preeclamptics & $8.27 \pm 0.37$ & \multirow{2}{*}{$<0.0001$} & \multirow{2}{*}{$\begin{array}{l}\text { Difference } \\
\text { is extremely } \\
\text { statistically } \\
\text { significant }\end{array}$} \\
\hline Control & $9.06 \pm 0.27$ & & \\
\hline
\end{tabular}

Table 3: Comparison of serum magnesium between preeclamptics and control groups.

\begin{tabular}{|c|c|c|c|}
\hline Group & $\begin{array}{l}\text { Serum } \\
\text { magnesium } \\
\text { (mg/dL) } \\
\text { Mean } \pm \text { SD }\end{array}$ & P value & Inference \\
\hline Preeclamptics & $1.99 \pm 0.13$ & \multirow{2}{*}{0.0308} & \multirow{2}{*}{$\begin{array}{l}\text { Difference is } \\
\text { statistically } \\
\text { significant }\end{array}$} \\
\hline Control & $2.03 \pm 0.13$ & & \\
\hline
\end{tabular}

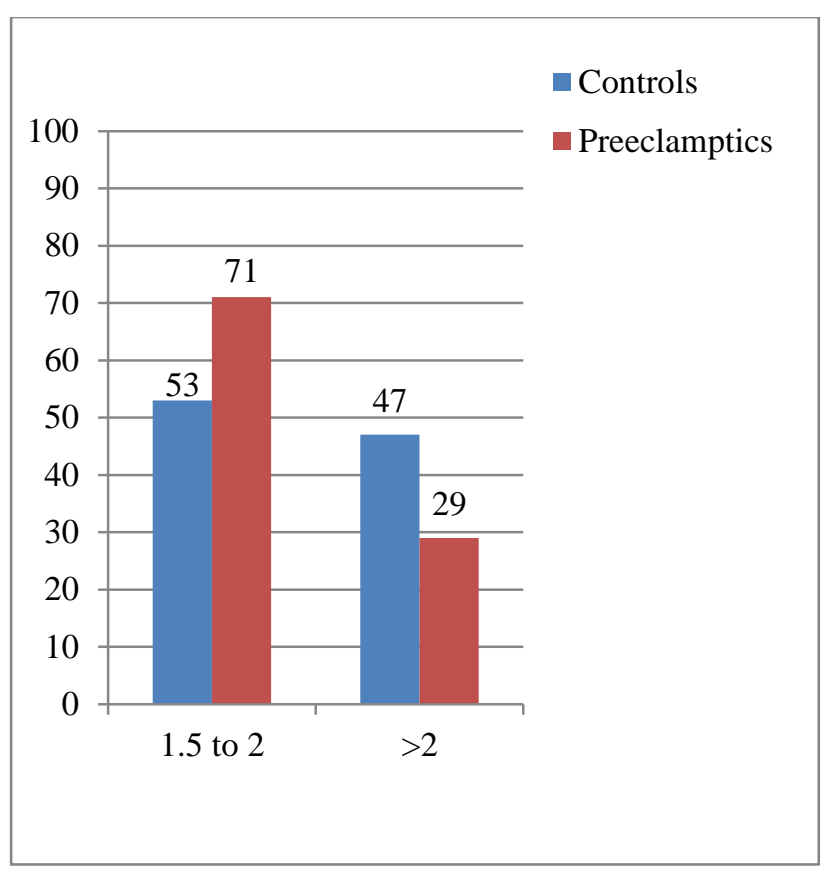

Figure 3: Comparison of serum magnesium between preeclamptics and control groups.

\section{DISCUSSION}

The physiological basis behind this hypothesis is that low calcium intake stimulates PTH production, which increases the intracellular calcium levels. This leads to smooth-muscle vessel contraction and hypertension. Calcium supplements would reduce the intracellular calcium and relax the vessels. ${ }^{13}$ Generally, hypomagnesaemia associated with haemodilution, altered renal clearance and consumption of minerals by the growing fetus ${ }^{10}$. Magnesium is essential cofactor for enzymes and plays an important role in neurochemical transmission and peripheral vasodilatation.

The comparison of serum calcium and serum magnesium levels in cases and control of different studies has been shown by the following Tables.

Table 4: Comparative study of serum calcium in different research papers.

\begin{tabular}{|lll|}
\hline $\begin{array}{l}\text { Author (year) } \\
\begin{array}{l}\text { Malas } \mathrm{NO}^{11} \\
(2001)\end{array}\end{array}$ & $\begin{array}{l}\text { Preeclamptic } \\
\text { women }\end{array}$ & $\begin{array}{l}\text { Normal pregnant } \\
\text { women (control) }\end{array}$ \\
\hline $\begin{array}{l}\text { Chanvitya } \mathrm{P}^{10} \\
(2008)\end{array}$ & $8.7 \pm 0.4 \mathrm{mg} / \mathrm{dL}$ & $9.7 \pm 0.7 \mathrm{mg} / \mathrm{dL}$ \\
\hline Alavi A $^{14}(2012)$ & $7.88 \pm 0.94 \mathrm{mg} / \mathrm{dL}$ & $8.28 \pm 0.77 \mathrm{mg} / \mathrm{dL}$ \\
\hline $\begin{array}{l}\text { Chaurasia PP } \\
(2012)\end{array}$ & $8.9 \pm 0.4 \mathrm{mg} / \mathrm{dL}$ & $9.7 \pm 0.7 \mathrm{mg} / \mathrm{dL}$ \\
\hline $\begin{array}{l}\text { Present study } \\
(2013)\end{array}$ & $8.27 \pm 0.37 \mathrm{mg} / \mathrm{dL}$ & $9.6 \pm 0.27 \mathrm{mg} / \mathrm{dL}$ \\
\hline
\end{tabular}


Table 5: Comparative study of serum magnesium in different research papers.

\begin{tabular}{|c|c|c|}
\hline Author (year) & $\begin{array}{l}\text { Preeclamptic } \\
\text { women }\end{array}$ & $\begin{array}{l}\text { Normal pregnant } \\
\text { women (control) }\end{array}$ \\
\hline $\begin{array}{l}\text { Sukopan } K^{6} \\
\text { (2005) }\end{array}$ & $0.77 \pm 0.08 \mathrm{mmol} / \mathrm{L}$ & $0.85 \pm 0.09 \mathrm{mmol} / \mathrm{L}$ \\
\hline $\begin{array}{l}\text { Vahidrodsari } \\
\mathrm{F}^{7}(2008)\end{array}$ & $1.92 \pm 0.37 \mathrm{mg} / \mathrm{dL}$ & $2.29 \pm 0.69 \mathrm{mg} / \mathrm{dL}$ \\
\hline $\begin{array}{l}\text { Sendhav } S^{15} \\
(2013)\end{array}$ & $1.64 \pm 3.5 \mathrm{mg} / \mathrm{dL}$ & $2.12 \pm 0.17 \mathrm{mg} / \mathrm{dL}$ \\
\hline $\begin{array}{l}\text { Sayyed } \mathrm{AK}^{16} \\
(2013)\end{array}$ & $1.28 \pm 1.08 \mathrm{mg} / \mathrm{dL}$ & $1.80 \pm 0.47 \mathrm{mg} / \mathrm{dL}$ \\
\hline $\begin{array}{l}\text { Present study } \\
\text { (2013) }\end{array}$ & $1.99 \pm 0.13 \mathrm{mg} / \mathrm{dL}$ & $2.03 \pm 0.13 \mathrm{mg} / \mathrm{dL}$ \\
\hline
\end{tabular}

The above findings show that hypocalcaemia could be a risk factor for the development of preeclampsia. This data support the hypothesis that calcium might be a cause in the development of preeclampsia. The effect of serum calcium and its correlation with change in blood pressure could be explained by the level of intracellular concentration of calcium. When serum calcium concentration decreases; there is an increase of intracellular calcium concentration; which leads to the constriction of smooth muscles in blood vessels and also increases in vascular resistance.

\section{CONCLUSION}

Our study shows that both serum calcium and serum magnesium in preeclamptic pregnant women were lower when compared with normal pregnant women. These findings support the hypothesis that hypocalcaemia and hypomagnesaemia are possible etiologies of preeclampsia. However, calcium and magnesium supplement in pregnant women for the prevention of preeclampsia requires further study.

Funding: No funding sources

Conflict of interest: None declared

Ethical approval: The study was approved by the ethics committee of SAMC \& PGI, Indore

\section{REFERENCES}

1. Freinkel N. Effects of the conceptus on maternal metabolism during pregnancy. In: Leibel BS, Wrenshall GA, eds. On the Nature and Treatment of Diabetes. 2nd ed. Amsterdam: Excerpta Medica; 1965: 679-688.

2. Indumati K, Kodliwadmath MV, Sheela MK. The role of serum electrolytes in pregnancy induced hypertension. J Clin Diagn Res. 2011;5(1):66-9.
3. Redman CWG, Jefferis M. Revised definition of preeclampsia. Lancet. 1988;1:809-12.

4. Pridjan G, Puschett JB. Preeclampsia part-1 clinical and pathophysiologic considerations. Obstet Gynaecol Surv. 2002;57:598-618.

5. Walker JJ. Preeclampsia. Lancet. 2000;356:1260-5.

6. Sukonpan K, Phupong V. Serum calcium and serum magnesium in normal and preeclamptic pregnancy. Arch Gynaecol Obstet. 2005;273:12-6.

7. Vahidrodsari F, Ayati S, Tourabizadeh A, AyatAllahi H, Esmaeli H, Shahabian M. Serum calcium and magnesium in preeclamptic and normal pregnancies: a comparative study. J Reprod Infertil. 2008;9(3):256-62.

8. Repke JT, Villar J. Pregnancy-induced hypertension and low birth weight: the role of calcium. Am J Clin Nutr. 1991;54:237S-41S.

9. Chaurasia PP, Jadav PA, Jasani JH. Changes in serum calcium and magnesium level in preeclampsia vs. normal pregnancy. Int J Biomed Adv Res. 2012;3(6):511-3.

10. Chanvitya P, Boonsri K. Serum calcium, magnesium and uric acid in preeclampsia in normal pregnancy. $\mathrm{J}$ Med Assoc Thailand. 2008;91(7):968-73.

11. Malas NO, Shurideh ZM. Does serum calcium in pre-eclampsia and normal pregnancy differ? Saudi Med J. 2001 Oct;22(10):868-71.

12. Juha R, William EW, Michael K, Leila R. Bone and mineral metabolism. In: Burtis CA, Ashwood ER, Bruns DE, eds. Tietz Text Book of Clinical Chemistry and Molecular Diagnostics. 5th ed. Philadelphia: W.B. Saunders; 2012: 1733-1801.

13. Atallah AN, Hofmeyr GJ, Duley L. Calcium supplementation during pregnancy for preventing hypertensive disorders and related problems. Cochrane Database Syst Rev. 2010 Aug;(8):CD001059.

14. Alavi A, Jahanshahi KA, Karimia S, Arabzadea N, Fallahi S. Comparison of serum calcium, total protein and uric acid levels between hypertensive and healthy pregnant women in an Iranian population. Life Sci J. 2012;9(4):485-8

15. Sendhav S, Khubchandani A, Gandhi P, Sanghani H, Sidhu G, Vadhel A. A comparative study of serum uric acid, calcium and magnesium in preeclampsia and normal pregnancy. $\mathbf{J}$ Adv Res Biol Sci. 2013;5(1):55-8.

16. Sayyed AK, Sonttake AN. Electrolyte status in preeclampsia. Online Int Interdiscipl Res J. 2013 May-June;3(3):30-6.

DOI: $10.5455 / 2320-1770 . i j \operatorname{cog} 20141216$

Cite this article as: Mittal S, Shaikh MKS, Thakur R, Jain D. Comparison of serum calcium and magnesium levels between preeclamptic and normotensive healthy pregnant women. Int J Reprod Contracept Obstet Gynecol 2014;3:959-62. 